\title{
RANCANG BANGUN APLIKASI E-REPORT PENGADUAN MASYARAKAT DESIGN PUBLIC COMPLAINT E-REPORT APPLICATION
}

\author{
Roviana H. Dai, Lillyan Hadjaratie \& Nuzran Firmansyah Bouti \\ Universitas Negeri Gorontalo \\ e-mail: roviana.ung@gmail.com
}

\begin{abstract}
Ombudsman of the Republic of Indonesia is a National Institution which is in charge of receiving reports of Alleged maladministration. The representative institution of Gorontalo received sufficiently significant number of report for 122 in 2014, 138 reports in 2015, and 146 reports in 2016. High load of report accomplishment by one assistant leads to unresolved reports. The research aims at proposing a system which can be considered as early warning system, reminder and assistance of report monitoring by ombudsman representative officer of Gorontalo and people. The system applies sms gateway feature and web based system. Research findings are the application of e-report which can assist head office and assistant to handle daily public complaint.
\end{abstract}

Keywords: Ombudsman Representative of Gorontalo, e-report, Complaint Report of Maladministration.

\begin{abstract}
ABSTRAK
Ombudsman RI merupakan lembaga negara yang bertugas menerima laporan dugaan maladministrasi. Ombudsman RI perwakilan provinsi Gorontalo menerima jumlah laporan yang cukup signifikan setiap tahunnya yaitu 122 laporan ditahun 2014, 138 laporan ditahun 2015 dan 146 laporan sepanjang tahun 2016. Tingginya beban penyelesaian laporan setiap Asisten mengakibatkan laporan-laporan jadi tidak tertanggulangi. Adapun tujuan dari penelitian ini yaitu mengusulkan sebuah sistem yang dapat menjadi early warning system, reminder/pengingat sekaligus membantu dalam monitoring laporan baik oleh internal Ombudsman maupun masyarakat sebagai Pelapor. Sistem yang akan dibuat menggunakan fitur sms gateway dan sistem berbasiskan web. Hasil dari penelitian ini yaitu dibuatkannya aplikasi e-report yang bisa membantu Pimpinan dan Asisten dalam penanganan laporan pengaduan masyarakat setiap harinya.
\end{abstract}

Kata kunci: Ombudsman RI Provinsi Gorontalo, e-Report, Laporan Pengaduan Maladministrasi

\section{PENDAHULUAN}

Ombudsman RI merupakan lembaga negara yang memiliki tugas memiliki tugas antara lain adalah menerima laporan atas dugaan maladministrasi dalam penyelenggaraan pelayanan publik serta menindak lanjuti laporan tersebut (Pasal 7 UU No. 37 Tahun 2008 tentang Ombudsman RI).

Berdasarkan hasil wawancara dengan salah satu asisten Ombudsman RI di perwakilan provinsi Gorontalo disebutkan bahwa dalam proses penanganan sebuah kasus laporan maladministrasi tersebut membutuhkan waktu bervariasi sesuai dengan tingkat kesulitan laporan yang diterima oleh Ombudsman. Untuk laporan kategori ringan biasanya ditangani dalam waktu kurang dari 14 hari, sedangkan untuk laporan kategori sedang dan berat dapat memakan waktu penanganan tiga minggu hingga 6 bulan.

Konsekuensinya beban penyelesaian laporan setiap asisten Ombudsman RI khususnya di perwakilan provinsi Gorontalo tergolong tinggi. Sementara dalam penerimaan dan penanganan laporan seorang asisten Ombudsman memiliki kewajiban administratif yang sangat banyak misalnya pembuatan resume laporan, pemeriksaan/verifikasi substantif, pemberitahuan kepada Pelapor, 
korespondensi dan klarifikasi kepada Terlapor, laporan hasil pemeriksaan, laporan hasil klarifikasi hingga berita acara dan pemberitahuan penutupan. Hal ini mengakibatkan beban kerja administratif sesuai dengan standar operasional prosedur Ombudsman yang diatur dalam UU dan Peraturan Ombudsman. Mengakibatkan ada laporan - laporan yang tidak tertangangi sempurna secara administratif.

Dari permasalahan di atas, penulis mengusulkan sebuah sistem yang dapat menjadi early warning system, reminder/pengingat sekaligus membantu dalam monitoring laporan baik oleh internal Ombudsman maupun masyarakat sebagai Pelapor. Sistem ini juga diharapkan dapat mengurangi dan mencegah terjadinya laporan pengaduan yang tidak tertangani sesuai ketentuan waktu tindak lanjut dan mempermudah Pelapor untuk mengecek dan mengetahui jejak dan perkembangan penanganan laporan yang telah dilakukan oleh Ombudsman. Sistem ini juga dapat berfungsi sebagai arsip digital laporan pengaduan maladministrasi untuk kantor perwakilan provinsi Gorontalo.

Ruang lingkup dari sistem ini yaitu: (1) sistem ini memberitahukan masyarakat/pelapor tentang status terkini laporan melalui dua cara yaitu anjungan front office yang dapat diakses dengan mengunjungi Ombudsman RI provinsi Gorontalo dan menggunakan sms dengan mengirim pesan ke nomor Ombudsman RI provinsi Gorontalo; (2) Sistem tidak menjembatani interaksi antara pegawai dan pelapor melainkan menyediakan informasi status dari kasus maladministrasi untuk pelapor; (3) Sistem yang dibuat untuk Ombudsman wilayah provinsi Gorontalo; (4) Sistem yang dibuat dapat melakukan tracking aktifitas terhadap perubahan status laporan; dan (5) Sistem yang akan di buat berbasis web dengan sms gateway.
Menurut Alter (1992) Sistem Informasi adalah kombinasi antara prosedur kerja, informasi, orang, dan teknologi informasi yang diorganisasikan untuk mencapai tujuan dalam sebuah organisasi. Sedangkan menurut Gelinas, Oram dan Wiggins (1990) Sistem Informasi adalah sistem buatan manusia yang secara umum terdiri atas sekumpulan komponen dan manual yang dibuat untuk menghimpun, menyimpan, dan mengelola data serta menyediakan informasi keluaran kepada para pemakai. SMS Gateway adalah suatu platform yang menyediakan mekanisme untuk menghantar dan menerima sms dari peralatan mobile (HP, PDA phone, dll). (Thoyib, 2010). Dalam penerapan sms gateway peneliti menggunakan gammu dalam pengaplikasiannya. Pengelolaan basis data secara fisik tidak dilakukan oleh pemakai secara langsung, tetapi ditangani oleh sebuah perangkat lunak (sistem) yang khusus. Perangkat lunak inilah yang disebut DBMS/Database Management System yang akan menentukan bagaimana data diorganisasi, disimpan, diubah, dan diambil kembali. Juga menerapkan mekanisme pengamanan data, pemakaian data secara bersama, pemaksaan keakuratan/konsistensi data, dan sebagainya (Fathansyah, 2012). Perangkat lunak yang termasuk DBMS antara lain (Fathansyah, 2012): (1) dBase, FoxBase, Rbase MS-Access, dan Borland-Paradox (untuk DBMS sederhana); dan (2) MS-SQL Server, Oracle, IBM DB2, Informix, Sybase, MySQL, PostgreSQL (untuk DBMS yang lebih kompleks dan lengkap).

\section{METODE}

Metode yang digunakan dalam penelitian ini mengacu pada metode pengembangan sistem prototyping. Menurut Pressman (2010), dalam melakukan perancangan sistem yang akan dikembangkan dapat mengunakan metode prototype. Metode ini cocok digunakan untuk mengembangkan sebuah perangkat yang akan dikembangkan kembali. 
Tahapan - tahapan penelitian menggunakan metode prototyping antara lain: (1) Komunikasi. Pada tahapan awal penelitian, peneliti melakukan komunikasi dengan stakeholders dalam hal ini pihak Ombudsman RI perwakilan gorontalo, yang bertujuan untuk menganalisis flow / alur kerja yang ada di Ombudsman untuk mengetahui pada tahapan mana biasanya penanganan maladministrasi mengalami kendala dan apa saja yang yang bisa menghambat kinerja asisten penanggung jawab di Ombudsman RI perwakilan Gorontalo. Indikator keberhasilan pada tahap ini yaitu menciptakan sebuah sistem yang membatu masyarakat dalam menyediakan informasi kepastian status kasus maladminstrasi yang dilaporkan dan membantu mengingatkan asisten jika ada sebuah kasus yang sudah melebihi batas waktu tunggu operasional yang ada; (2) Rencana cepat dan pemodelan desain cepat. Pada tahap ini peneliti membuat desain cepat berdasarkan hasil dari proses komunikasi dengan pihak stakeholders yang nantinya akan dijadikan sumber referensi pada tahap pengembangan prototype. Indikator keberhasilan pada tahap ini mengahasilkan sebuah desain yang menggambarkan secara umum yang selanjutnya akan dikembangkan lagi; (3) Pembangunan Prototipe. Pada tahap ini, berdasarkan hasil dari quick design, peneliti membangun sebuah prototype, menggambarkan secara umum tentang pengembangan yang akan dilakukan terhadap sistem atau pertangkat lunak. Indikator keberhasilan pada tahap ini yaitu membangun sebuah prototype yang dapat dipahami oleh stakeholders yang memuat gambaran umum terhadap pengembangan sistem; (4) Penerapan aplikasi dan umpan balik. Tahapan ini merupakan tahap dimana prototype yang selesai dibuat diberikan kepada stakeholders kemudian feedback (umpan balik) yang diterima di diimplementasikan kedalam bahasa pemograman dan menghasilkan suatu sistem atau perangkat lunak jadi dan siap pakai. Indikator keberhasilan pada tahap ini yaitu menghasilkan sebuah sistem atau perangkat lunak jadi dan siap pakai yang merupakan solusi dari masalah-masalah yang didapati pada sistem yang lama; dan (5) Penyusunan Laporan. Hasil dari penelitian ini akan disusun dalam bentuk laporan yang menggambarkan tahapan penelitian mulai dari tahap awal hingga selesai.

\section{HASIL}

Pada tahapan komunikasi, melalui hasil wawancara didapatkan daftar pengguna sistem serta fungsi dari tiap - tiap pengguna sistem dengan detail sebagai berikut: (1) Admin untuk (a) Mengkonfigurasi sistem, Admin dapat mengatur pengaturan - pengaturan umum (seperti: jumlah dan biodata kabupaten, dan seterusnya); (b) Menginput pengguna, Admin dapat menambah, mengurangi, menghapus user yang akan menggunakan sistem ini; (2) Asisten untuk (a) mengubah status laporan. Asisten dapat mengubah status dari laporan yang dimasukkan oleh masyarakat/pelapor; (b) pemberitahuan kasus lebih dari 14 hari (pesan singkat /sms). Pemberitahuan kasus/laporan tersebut dalam bentuk pesan singkat ke nomor asisten penanggung jawab kasus/laporan tersebut; (3) Asisten Penanggung Jawab Registrasi untuk (a) Input data pelapor, Asisten dapat menginput data pelapor ke sistem; (b) Input data laporan, Asisten dapat menginput kasus/laporan atau sering disebut dengan registrasi data ke dalam system; (4) Pimpinan untuk Pemberitahuan kasus lebih dari 14 hari (pesan singkat /sms). Pimpinan akan mendapatkan pemberitahuan kasus yang penanganannya sudah lebih dari 14 hari tetapi belum ada perubahan kedalam sistem; dan (5) Masyarakat/Pelapor untuk (a) Cek status laporan melalui web, Pelapor dapat mengecek status terbaru dari kasus yang mereka laporan melalui browser komputer/laptop atau smartphone mereka; (b) Cek status laporan melalui pesan singkat, Pelapor juga dapat mengecek status terbaru dari kasus yang mereka laporkan melalui pesan singkat ke nomor Ombudsman. 


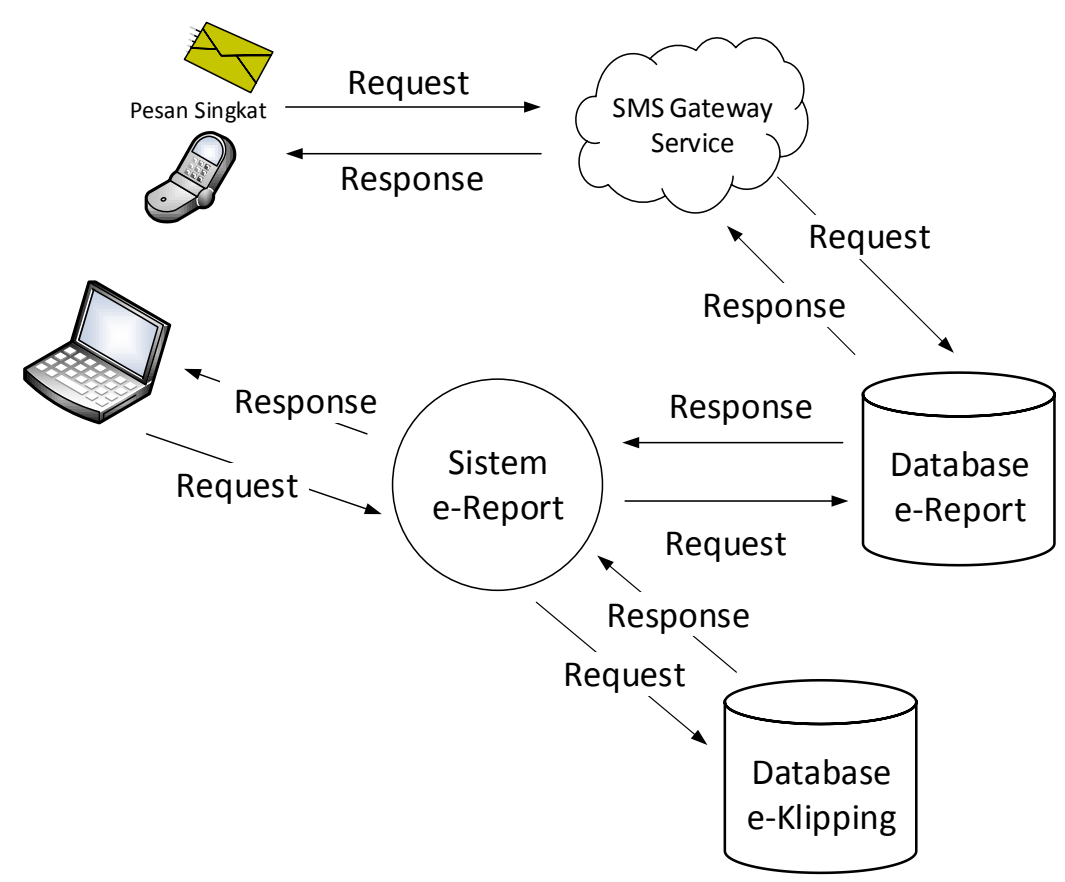

Gambar 1. Rancangan Arsitektur Sistem

Implementasi pada sistem e-report yang diperlihatkan pada gambar 1 adalah sistem e-report menggunakan 1 penyimpanan data $e$-report dan 1 lagi penyimpanan data $e$ klipping, penyimpanan data e-report adalah penyimpanan data utama dari aplikasi itu sendiri sedangkan penyimpanan data $e$ klipping adalah penyimpanan data dari aplikasi terpisah tempat sistem e-report mengambil data pelapor, instansi terlapor dan ringkasan laporan sebagai bentuk dari integrasi data antar aplikasi e-report dan e-klipping, pengguna sistem bisa mengakses informasi dari sistem menggunakan dua cara yaitu sms/pesan singkat dan melalui browser komputer ataupun laptop.Jika menggunakan pesan singkat, pesan singkat akan diterima oleh sms gateway dimana dalam pengiriman pesan singkat itu sendiri menggunakan format yang dikenali oleh service sms gateway itu sendiri, kemudian jika format yang dikirimkan tidak sesuai maka akan secara otomatis dibalas dengan pemberitahuan bahwa format penulisan pesan singkat yang dikirimkan tidak sesuai. Dan jika format yang dikirimkan sesuai maka service sms gateway akan mengambil data status yang berada di database e-report yang kemudian akan di kirimkan kembali kepada pengirim pesan menggunakan service sms gateway.

Selanjutnya melalui komputer/laptop dengan cara mengakses url dengan menggunakan browser yang kemudian akan menampilkan tampilan aplikasi e-report. Untuk pemberitahuan kasus yang sudah melebihi 14 hari penanganannya memiliki alur sistem e-report melakukan pengecekan pada database e-report jika ada kasus yang sudah 14 hari lebih belum mengalami perubahan maka sistem akan menginput perintah mengirimkan pesan singkat kepada asisten penanggung jawab melalui database sms gateway yang sudah terintegrasi dengan database e-report yang terhubung langsung dengan service sms gateway sehingga memungkinkan secara tidak langsung sistem e-report mengirimkan pesan singkat kepada asisten penanggung jawab kasus/laporan. Diagram konteks dan diagram alir data dapat ditunjukkan pada Gambar 2 dan Gambar 3. 


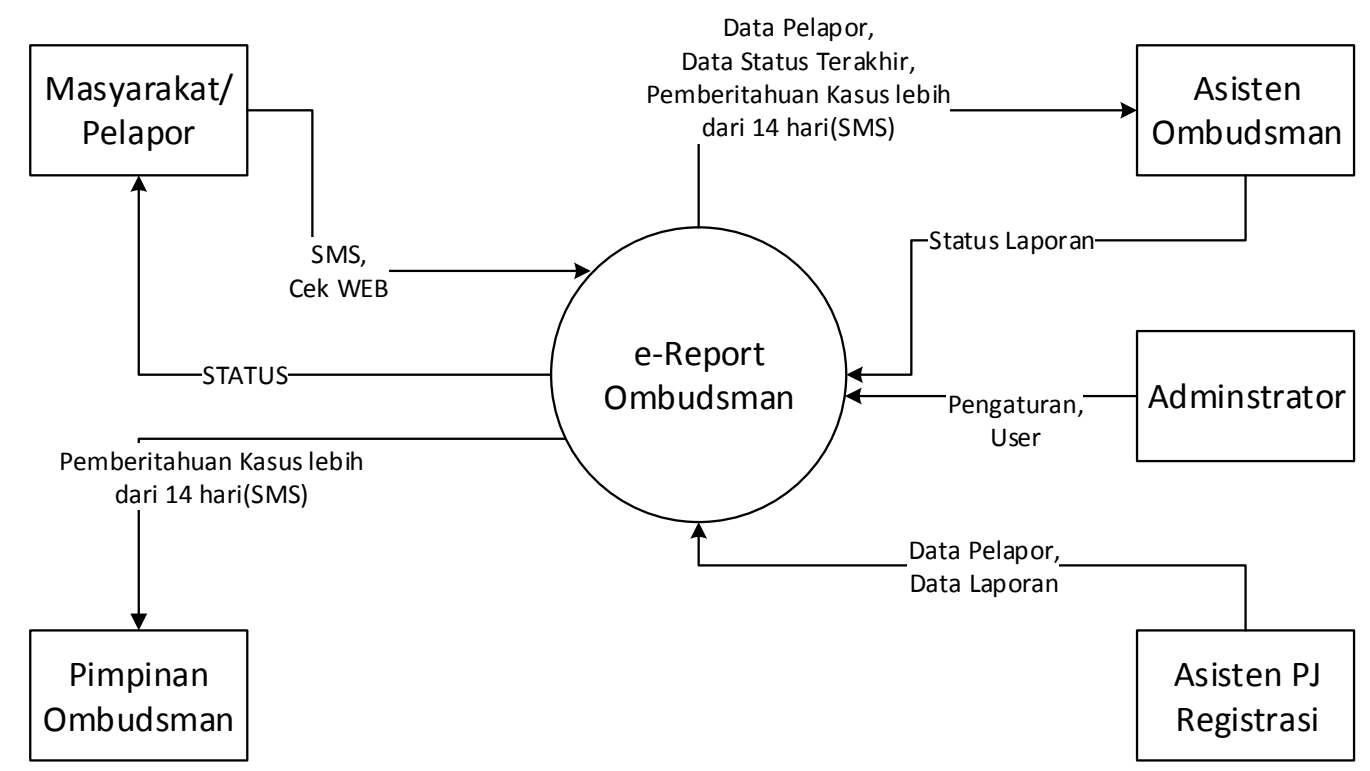

Gambar 2. Diagram Konteks

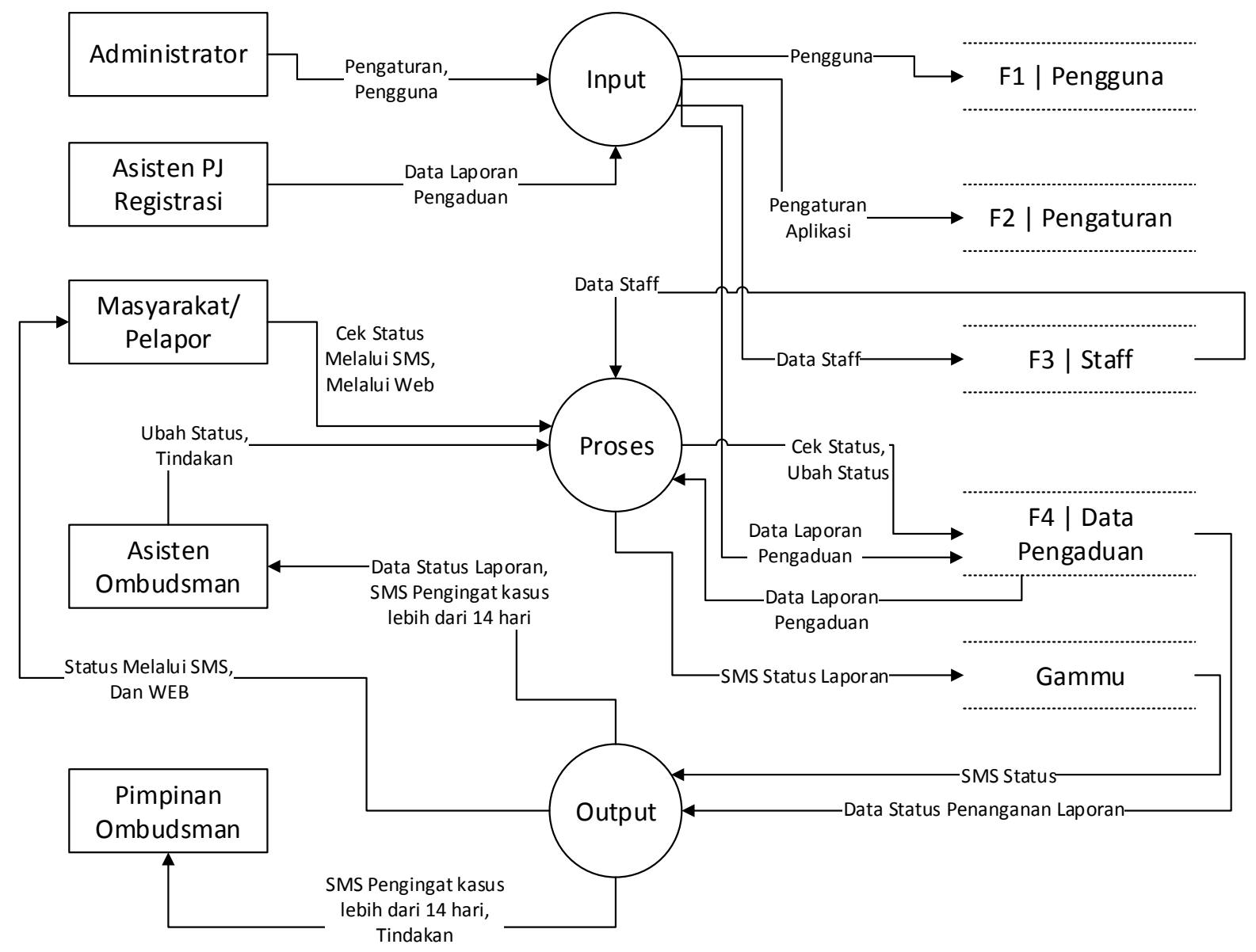

Gambar 3. Diagram Alir Data (DAD) 
Pembangunan Prototipe Halaman Cek Status dapat dilihat pada Gambar 4. Terdapat isian kode registrasi pada halaman ini.

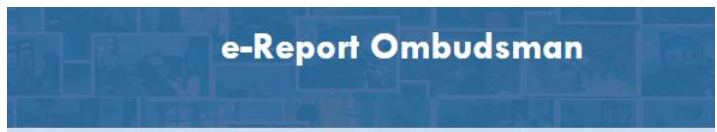

\section{CEK STATUS LAPORAN}

tahu perkembangan tindak lanjut laporan Anda Kode Registrasi :

$\square$

Status :

Asisten :

Gambar 4. Halaman Cek Status Laporan

Halaman Back Office Login dapat dilihat pada Gambar 5. Halaman tersebut membutuhkan username dan password dari pengguna untuk dapat melakukan akses.

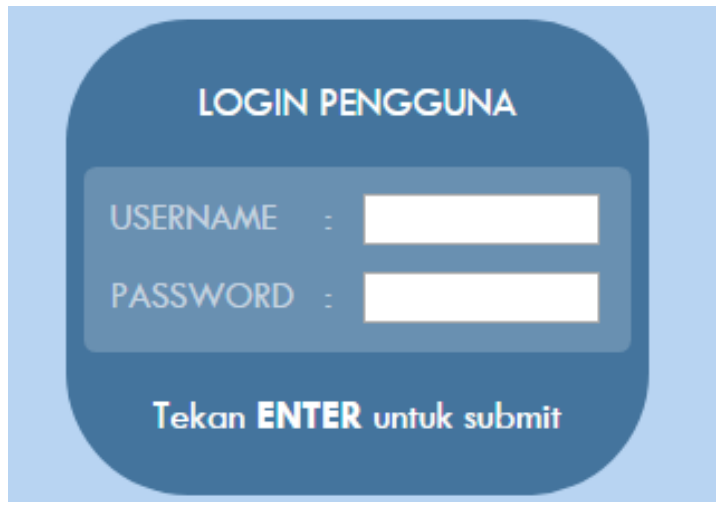

Gambar 5. Halaman Login Back Office
Halaman Rekam Data dapat dilihat pada Gambar 6. Halaman ini berisi perekaman data yang ada.

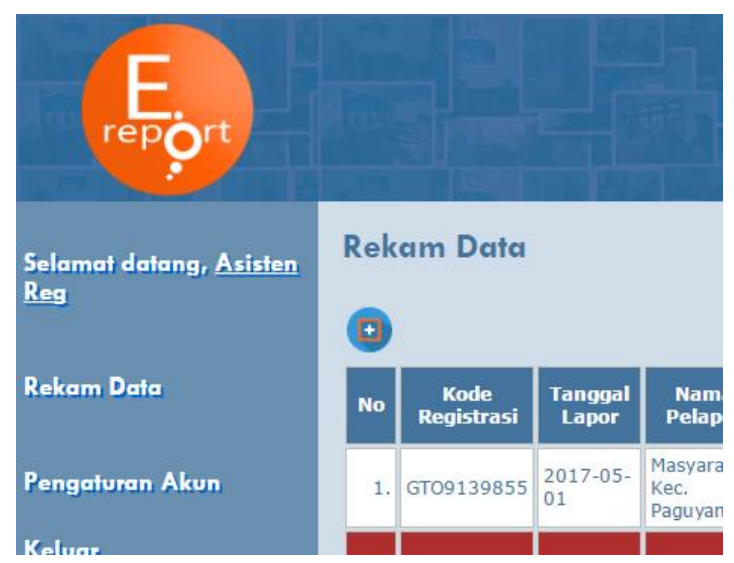

Gambar 6. Halaman Rekam Data

Halaman Ubah Status Laporan dapat dilihat pada Gambar 7. Terdapat fitur pencarian untuk memudahkan muncul data yang diinginkan.

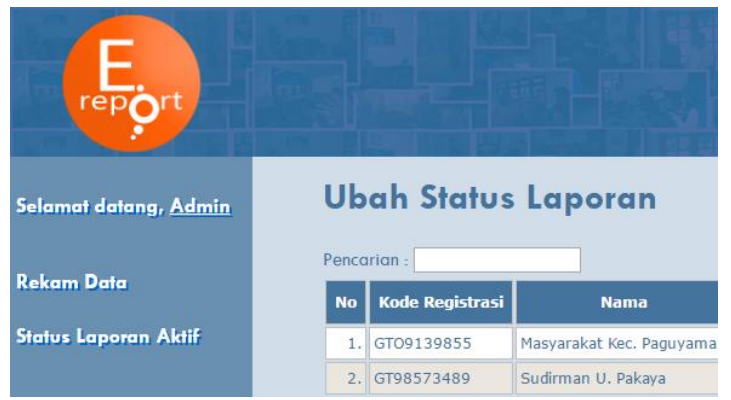

Gambar 7. Halaman Ubah Status

Laporan Aktif dapat dilihat pada Gambar 8.

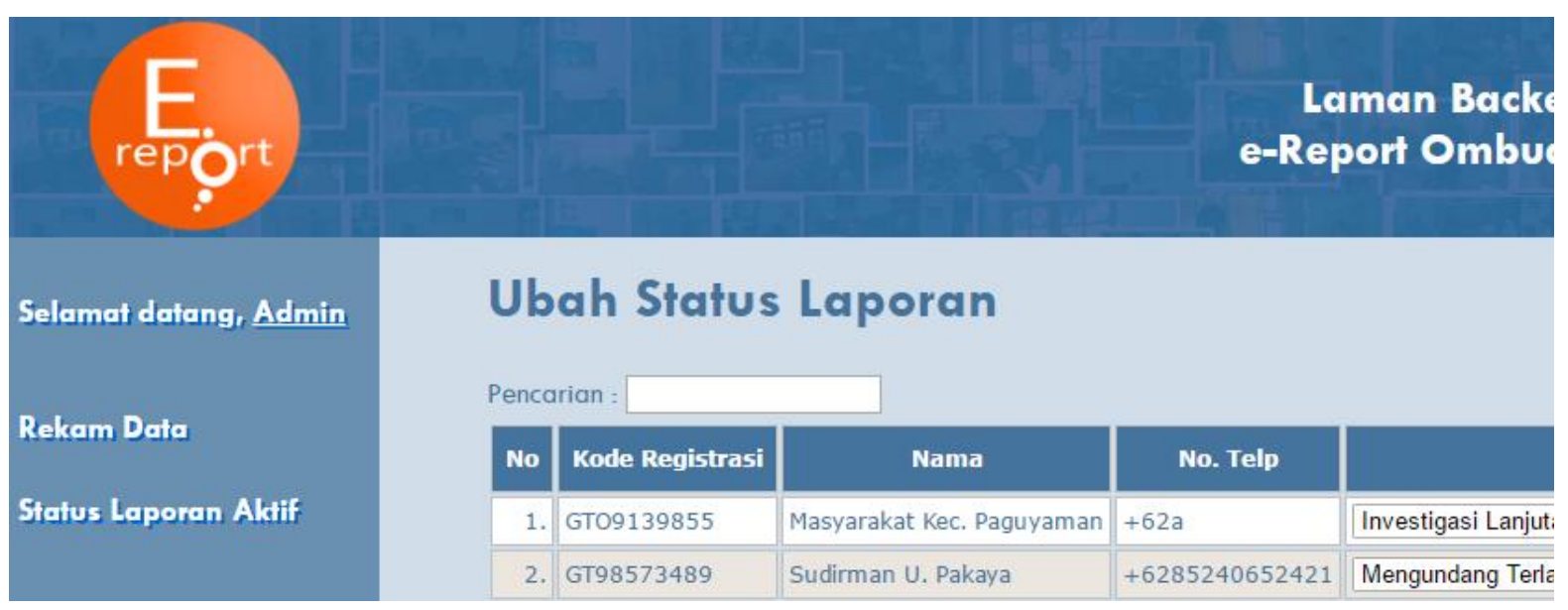

Gambar 8. Halaman Laporan Aktif 
Halaman Data Kontak dapat dilihat pada

Gambar 9.

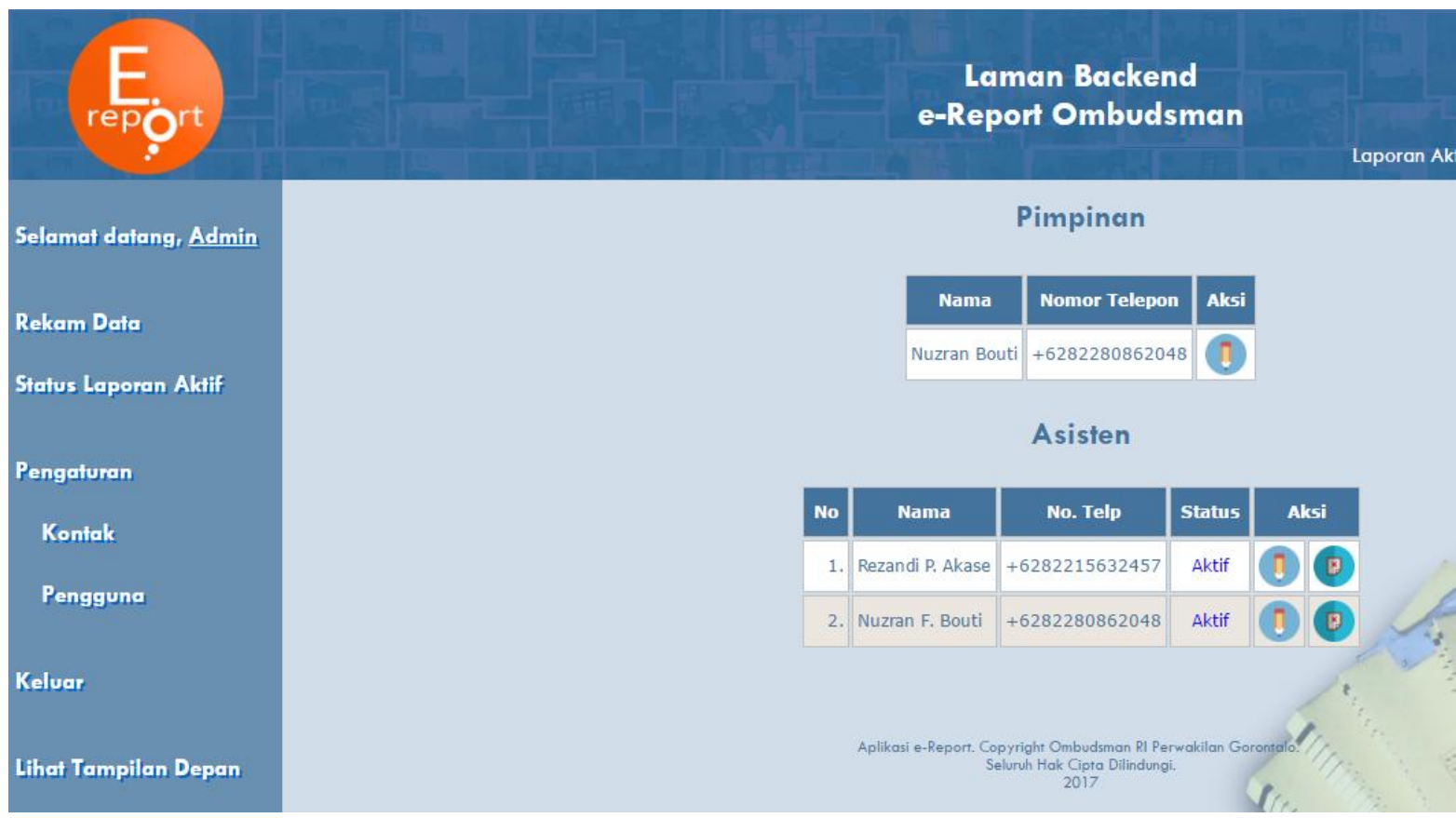

Gambar 9. Halaman Laporan Aktif

Pengaturan Akun dapat dilihat pada Gambar 10.

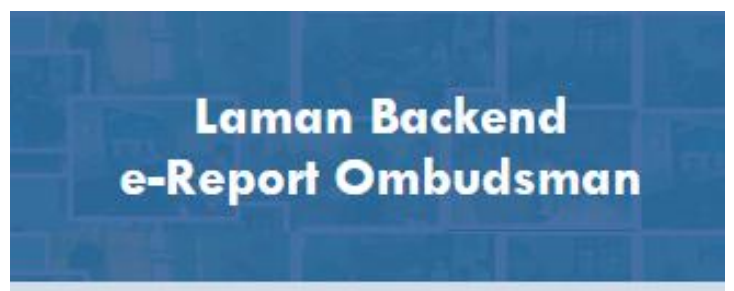

\section{Pengaturan Akun Anda}

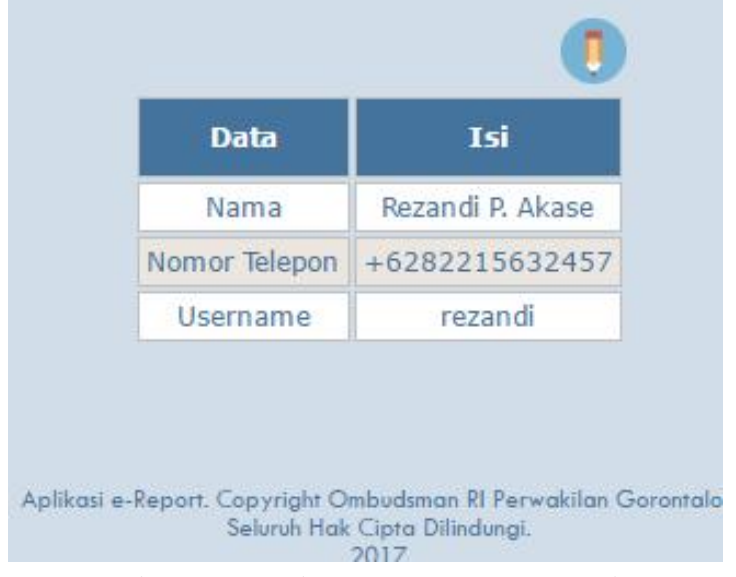

Gambar 10. Halaman Pengaturan Akun

Administrator Pengaturan dapat dilihat pada Gambar 11.

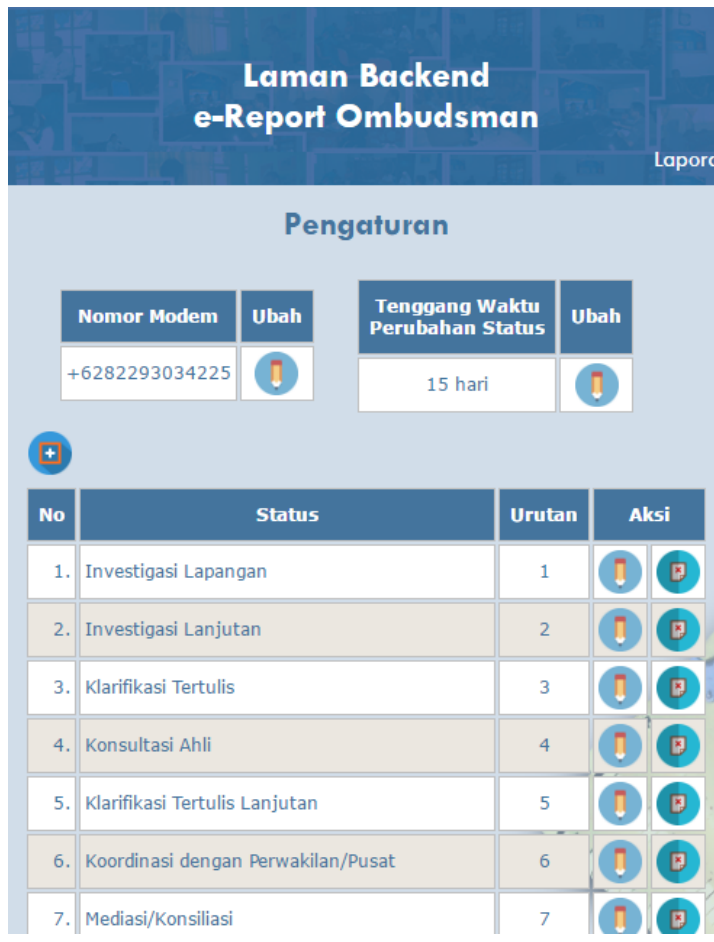

Gambar 11. Halaman Pengaturan Administrator

Administrator Pengaturan Pengguna dapat dilihat pada Gambar 12. 


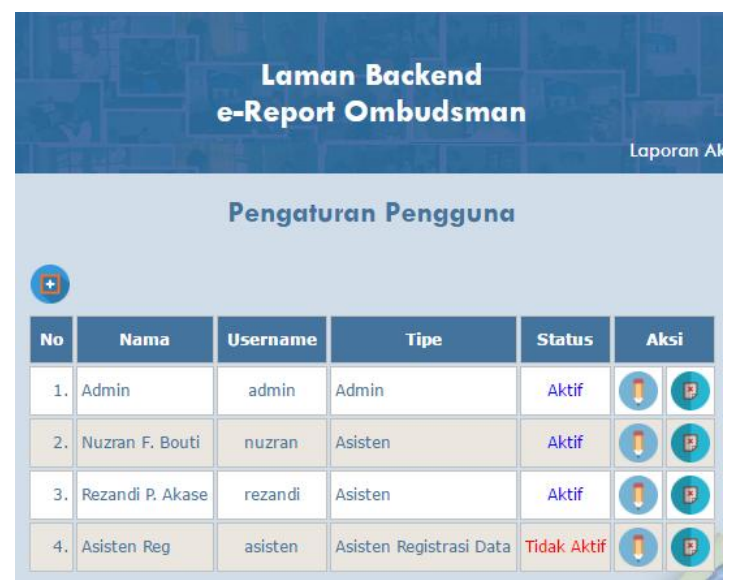

Gambar 12. Halaman Pengaturan pengguna

Terdapat fitur untuk melakukan penambahan pengguna. Halaman tambah pengguna dapat dilihat pada Gambar 13.

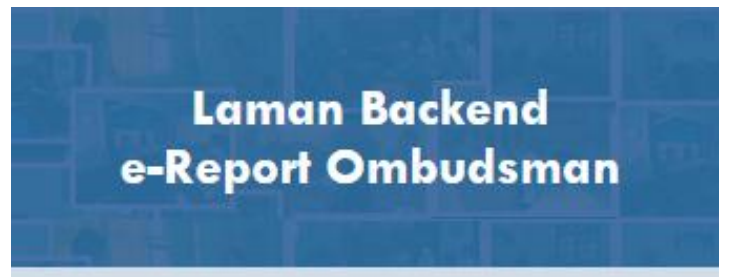

\section{Tambah Data Pengguna}

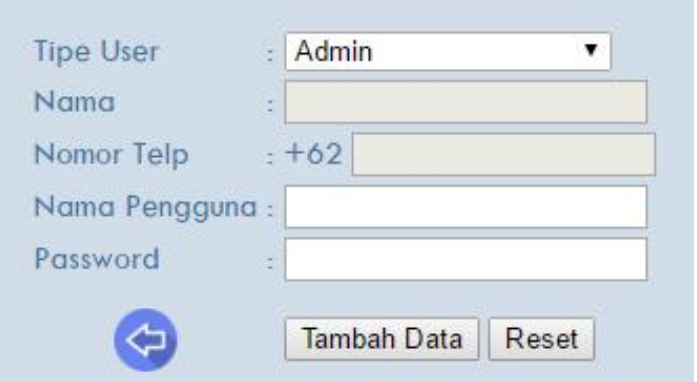

Gambar 13. Halaman Tambah pengguna

Selain penambahan pengguna, untuk pengguna yang sudah ada juga dapat dilakukan perubahan. Halaman Ubah Pengguna dapat dilihat pada Gambar 14.

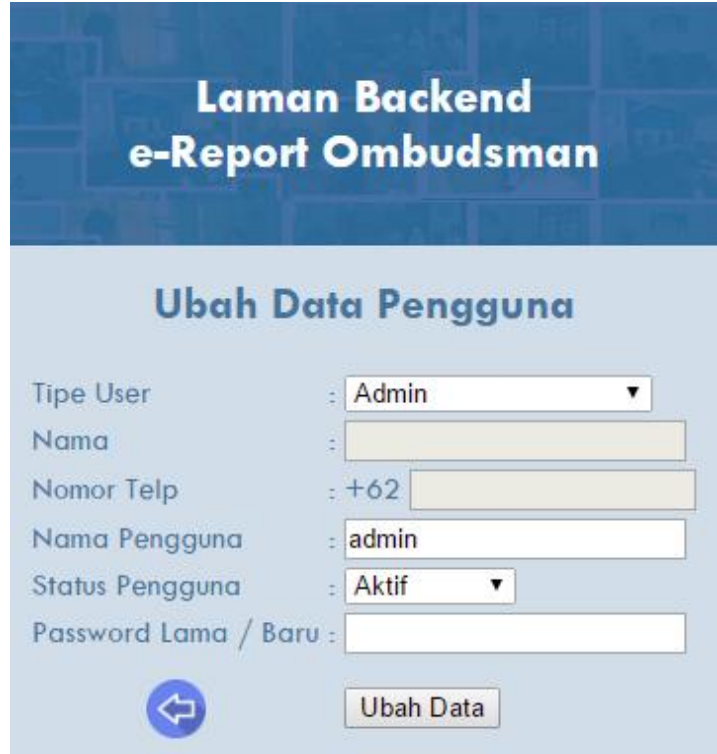

Gambar 14. Halaman Ubah pengguna

Pemberitahuan bagi pelaoran yang telah dilakukan kepada pelapor dapat diperoleh melalui adanya notifikasi. Notifikasi Terdaftar dalam Sistem dapat dilihat pada Gambar 15.

Terima kasih telah melapor ke
Ombudsman. Saat ini laporan Anda
telah terdaftar dengan Kode
Registrasi : GTO 8145509
Silahkan Melakukan Pengecekan
perkembangan kasus laporan anda
dengan mengirimkan sms ke nomor ini
dengan format INFO <spasi>
KODE_REGISTRASI
(Contoh : INFO <spasi> GTO0111110).

Gambar 15. Notifikasi Terdaftar dalam Sistem

Tampilan-tampilan aplikasi SMS penggunaan sistem ini dapat dilihat pada Gambar 16 sampai dengan Gambar 22.

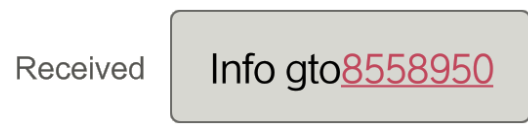

Gambar 16. Format SMS Pengecekan Status 


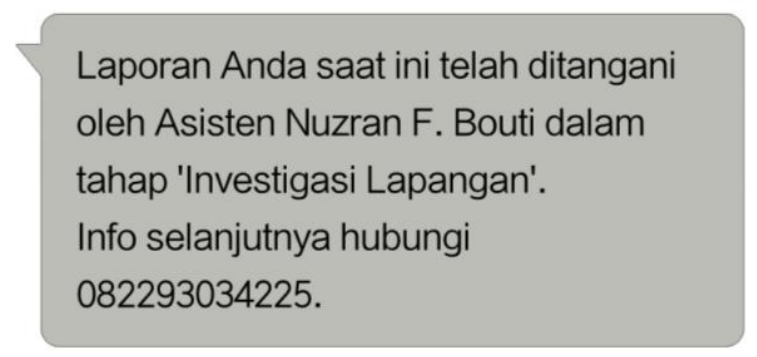

Gambar 17. Notifikasi Pengecekan Status oleh Masyarakat

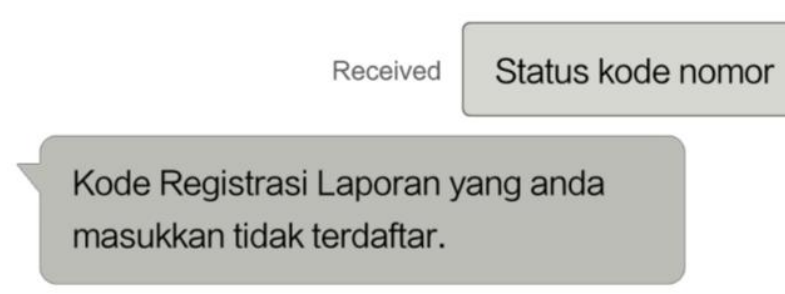

Gambar 18. Notifikasi Salah Memasukkan Nomor Laporan

\section{Received Status gtog139855 19}

Gambar 19. Format Pengubahan Status

$$
\text { Received Status gtog139855 } 3
$$

\section{Data Berhasil diubah.}

Gambar 20. Notifikasi Berhasil Update

Received

Status kode nomor

Kode Registrasi Laporan yang anda masukkan tidak terdaftar.

Gambar 21. Notifikasi Gagal Perbaharui Status

Setelah sistem telah selesai dibuat, akan dilakukan tahapan terakhir untuk menguji apakah sistem yang dibuat telah sesuai dengan keinginan pengguna atau belum. Untuk pengujian dari sistem e-report menggunakan alat pengujian black box.
Laporan dgn Nomor Registrasi:

16511163 yang anda tangani hingga

hari ke-15 ini, belum mengalami

perubahan status Laporan. Mohon

untuk segera ditindaklanjuti.

\section{Laporan dengan Nomor Registrasi:}

16511163 Penanggung Jawab: Nuzran

F. Bouti hingga hari ke-15 ini, belum

mengalami perubahan status Laporan.

Mohon untuk segera ditindaklanjuti.

Gambar 22. Notifikasi Lebih dari ketentuan dalam SOP tetapi status masih belum mengalami perubahan

Berdasarkan hasil tahapan-tahapan model penelitian yang telah dilakukan, peneliti berhasil mengembangkan sebuah sistem yang berfungsi sebagai pemberitahuan dan pengingat akan progress tahapan pengaduan kasus untuk internal ombudsman itu sendiri dan masyarakat sehingga bisa lebih memudahkan asisten dalam melayani masyarakat yang ingin tau tentang perkembangan kasus yang masyarakat laporkan. Fitur utama aplikasi ini terletak pada fitur sms gateway itu sendiri, karena masyarakat pada umumnya lebih terbiasa berkomunikasi menggunakan telepon genggam yang lebih khususnya lagi pesan singkat / sms. Sehingga untuk mengakses ataupun melacak informasi dari status terakhir laporan kasus mereka sangat mudah, yaitu dengan mengirimkan pesan singkat / sms ke nomor sms gateway ombudsman yang secara otomatis akan mengirimkan balasan status terakhir dari laporan kasus masyarakat beserta nama asisten penanggung jawab kasus tersebut. Karena sebelumnya masyarakat mengalami kendala dalam mendapatkan informasi perkembangan laporan kasus mereka tersebut. Asisten juga bisa melakukan pengubahan status dari laporan kasus maladministrasi oleh masyarakat melalui pesan singkat / sms seperti halnya masyarakat melakukan pengecekan terhadap laporan 
mereka, asisten mengirimkan pesan singkat / sms dari nomor asisten yang terdaftar didalam sistem ke nomor sms gateway sistem sesuai format yang berlaku dan sistem dengan sendirinya akan merubah status dari laporan masyarakat tersebut.

Dalam sistem e-report pengguna sistem terbagi atas tiga tipe pengguna yaitu, admin, asisten, dan asisten registrasi data. Admin memiliki akses untuk menambahkan pengguna dan melakukan pengubahan terhadap pengaturan - pengaturan yang ada didalam sistem e-report, selanjutnya asisten memiliki akses untuk pengubahan status dari laporan kasus yang dimasukkan oleh pengguna dengan tipe asisten registrasi data, dan terakhir asisten registrasi data adalah tipe pengguna yang memiliki fungsi sebagai penginput data laporan kasus kedalam sistem yang kemudian akan digunakan oleh tipe pengguna asisten..

\section{SIMPULAN}

Berdasarkan penelitian yang telah dilakukan tentang penanganan laporan pengaduan masyarakat melalui aplikasi ereport di ombudsman ri provinsi Gorontalo, diperoleh kesimpulan sebagai berikut: (1) Sistem yang dihasilkan merupakan sistem yang dibangun dan dibuat menggunakan bahasa pemrograman php serta menggunakan media penyimpanan data mysql dan gammu sebagai alat yang digunakan untuk mengirimkan pesan singkat / sms; (2) Sistem menyediakan media informasi data status laporan pengaduan masyarakat yang berbasis pesan singkat / sms yang sudah tergolong bisa dijangkau oleh seluruh masyarakat pada umumnya; (3) Sistem juga menyediakan fitur pengubahan status laporan pengaduan masyarakat melalui pesan singkat / sms yang terbilang cukup memudahkan karena asisten bisa memperbaharui status laporan pengaduan masyarakat dari manapun dan kapanpun.

\section{DAFTAR RUJUKAN}

Alter, S. 1992. Information System A Management Prespective. The Benjamin/Cumming Publishing Company Inc. USA.

Faaza, F.U. 2015. SMS Gateway Untuk Verifikasi Kehadiran Dosen Dalam Information Display System Jadwal Perkuliahan Di Prodi Informatika FKI UM. Skripsi diterbitkan (Online). Surakarta : Universitas Muhammadiyah Surakarta. http://eprints.ums.ac.id/37618/. Di akses pada $(16 / 3 / 2016)$

Fathansyah. 2012. Basis Data. Bandung: Informatika Bandung.

Gelinas, U.J., Oram, A.E., Wiggins, W.P. 1990. Accounting Information System. PWS-KENT Publishing Company.

Machmud, N.P. 2015. Sistem Pendukung Keputusan Pemilihan Tempat Kos menggunakan Metode Elimination Et Choix Traduisant La Realite (ELECTRE). Skripsi. Gorontalo : Universitas Negeri Gorontalo.

Pressman, R.S. 2010. Software Engineering : a practitioner's approach, McGraw-Hill, New York.

Sumadyo, M. 2009. Rancang Bangun Sistem Pelaporan Pendapatan Harian Dengan Sms Gateway Dan Monitoring Hasil Berbasis Web Pada Perusahaan Pengisian Ban Nitrogen. Jurnal Paradigma Vol X, 212-221.

Susanto, H. 2013. Rancang Bangun Sistem Informasi Pelaporan Perkembangan Gizi Balita Bagi Tingkat Kecamatan Pada Area Kecamatan Semarang Selatan. Jurnal UdiNus Repository. Vol. 1, No. 1. http://eprints.dinus.ac.id/12738/. Di akses pada (16/3/2016)

Thoyib. 2010. Pelayanan Pelanggan Berbasis SMS Gateway. JURNAL UMB, 3 